\title{
KARAKTERISTIK PROFIL JARINGAN LUNAK PADA PENDERITA OBSTRUKSI SALURAN NAPAS ATAS DENGAN KEBIASAAN BERNAPAS MELALUI MULUT
}

\author{
Erly Budianto*, Miesje K. Purwanegara**, Erwin Siregar*** \\ Departemen Ortodonti Fakultas Kedokteran Gigi Universitas Indonesia
}

Keywords:

Obstruction of the upper respiratory tract (OURT);

Mouth breathing habit;

Soft tissue profile

characteristics

\begin{abstract}
Obstruction of the upper respiratory tract (OURT) will cause mouth breathing that is known to influence neuromuscular activity. This will lead to malformation of face growth pattern and head posture that can result in dentocraniofacial deformity. This research aimed to identify the differences in soft tissue profile characteristics in OURT patients compared to normal subjects, and to analyze the differences between boys and girls in this respect. An analytic descriptive study with cross sectional design was applied. The sample consists of 96 subjects including 64 OURT patients ( 32 boys and 32 girls) and 32 normal subjects (11 boys and 21 girls). The results showed that the OURT patients had convex profile and longer distance than the normal subjects between upper or lower lip to esthetic line $(\mathrm{p}<0.05)$. Furthermore, normal male subjects had longer distance of upper lip to E-line than females $(p=0.039)$. The same was also shown in OURT patients, i.e. male patients had longer distance of upper and lower lip to E-line compared to females $(\mathrm{p}<0.05)$.
\end{abstract}

\section{Pendahuluan}

Estetika wajah yang seimbang dan oklusi fungsional yang baik merupakan salah satu tujuan perawatan ortodonti. Angle merupakan salah seorang ortodontis yang menulis mengenai keseimbangan wajah dan pentingnya profil jaringan lunak. Beliau mengatakan bahwa perawatan ortodonti terkait erat dengan wajah seseorang oleh karena mulut merupakan salah satu faktor yang berperan membentuk karakteristik wajah. $^{1}$

Pasien yang memerlukan perawatan ortodonti biasanya datang dengan kelainan dentokraniofasial. Kelainan ini disebabkan faktor genetik dan lingkungan. ${ }^{2}$ Faktor penyebab 
maloklusi adalah herediter dan faktor yang didapat. Faktor yang didapat diperinci menjadi gangguan perkembangan, trauma, faktor fisik, kebiasaan buruk, malnutrisi, dan penyakit. Perawatan ortodonti diharapkan dapat menyelesaikan masalah ketidakharmonisan posisi, hubungan gigi-geligi dan rahang. ${ }^{3}$

Fungsi pernafasan melalui hidung dan mulut mempengaruhi perkembangan wajah dan gigi-geligi. Cara bernafas menentukan postur kepala, rahang dan lidah. ${ }^{4}$ Oleh karena itu, pemeriksaan ada tidaknya pengurangan kemampuan pernafasan hidung penting untuk dilakukan. Obstruksi saluran nafas atas (OSNA) diartikan sebagai suatu keadaan yang ditandai oleh adanya sumbatan kronis saluran nafas atas pada kavitas nasal, nasofaring, atau orofaring. ${ }^{5}$

Adanya hambatan atau obstruksi saluran nafas atas mengakibatkan seseorang mencari alternatif cara bernafas melalui mulut, yang dilakukan secara total atau kombinasi hidung dan mulut. Bernafas melalui mulut diperkirakan dapat mempengaruhi aktivitas otot-otot orofasial seperti otot bibir, lidah. Perubahan aktivitas otot-otot tersebut dapat menuntun terjadinya penyimpangan pola pertumbuhan wajah dan postur kepala yang dapat mengakibatkan timbulnya deformitas dentofasial. ${ }^{6}$

Sampai saat ini, penelitian yang dilakukan pada umumnya berkaitan dengan analisis skeletal. Hal ini disebabkan adanya anggapan bahwa profil jaringan lunak berhubungan langsung dengan dengan profil skeletal di bawahnya. Subtelny mengatakan bahwa perubahan yang terjadi pada jaringan keras dan jaringan lunak tidak menunjukkan hubungan yang linear. Beliau melakukan pengukuran horisontal dan vertikal, dan menemukan bahwa tidak semua profil jaringan lunak mengikuti pola skeletal. Burstone menyetujui pendapat Subtelny dengan memberikan alasan bahwa variasi ketebalan jaringan lunak yang menutupi skeletal menjadi penyebab ketidaksesuaian antara profil jaringan lunak dengan jaringan keras di bawahnya. Adapun karakteristik profil jaringan lunak ini dapat diketahui melalui analisis sefalometri lateral. Ada beberapa cara penilaian jaringan lunak, antara lain: pengukuran menurut Steiner (garis S), Ricketts (garis E), Burstone, Sushner, Holdaway (garis H), Merrifield (sudut Z), Rakosi, dan Arnett. Kesemuanya memberikan informasi mengenai karakteristik profil jaringan lunak yang seringkali dipakai dalam perawatan ortodonti dan bedah ortognati. ${ }^{1}$

Case menyatakan bahwa dalam mengkoreksi maloklusi, profil wajah seseorang menjadi penuntun yang penting dalam menyusun rencana perawatan yang tepat. ${ }^{1}$ Oleh sebab itu, penelitian ini ditujukan untuk mengetahui karakteristik profil jaringan lunak penderita obstruksi saluran nafas atas (OSNA) dengan kebiasaan bernafas melalui mulut. Besar harapan para ortodontis diharapkan dapat lebih memperhatikan cara bernafas pasien sebagai bagian dari pemeriksaan klinis sehingga keberhasilan perawatan ortodonti dapat tercapai.

\section{Bahan dan Cara Kerja}

Populasi penelitian adalah anak ras Deuter omalayid dari Klinik THT RSUPN-CM FK UI, Klinik ortodonti RSGM-P FKG UI, SMPN 270 Cilacap dan SMPN 76, Jakarta Pusat. Subyek penelitian diambil dari populasi penelitian secara konsekutif.

Kriteria untuk subyek OSNA dengan nafas mulut yaitu adanya sumbatan kronis pada saluran napas atas pada kavitas nasal, nasofaring, atau orofaring, dengan kebiasaan buruk napas mulut. Kondisi ini didiagnosis melalui pemeriksaan fisik secara visual dan wawancara yang telah dilakukan oleh Purwanegara. Sedangkan untuk subyek normal, yaitu saluran napas atas pada kavitas nasal, nasofaring, atau orofaring normal tanpa kebiasaan buruk napas mulut. Subyek dengan penampilan dentokraniofasial normal dari sisi profil maupun frontal.

Kriteria inklusi subyek yaitu orang Indonesia ras Deuteromalayid usia 12-15 tahun. Kriteria eksklusinya pernah atau sedang dirawat ortodonti, memiliki riwayat asma atau penyakit sistemik lain, sedang batuk pilek akut, dan memiliki kebiasaan buruk oral lain, selain 
bernapas melalui mulut dan tongue thrust untuk subyek OSNA.

Bahan dan alat yang digunakan yaitu foto sefalometri yang baik, kertas asetat 0.003", pinsil $3 \mathrm{H}$, dan viewer. Cara kerja dimulai dengan, penapakan foto lateral di atas kertas asetat 0.003 " dengan bantuan viewer, penentuan titik dan garis referensi. Analisis statistik univariat untuk mendapatkan nilai rerata dan simpang baku dari masing-masing variabel dan bivariat untuk menguji perbedaan nilai rerata masing-masing variabel antara kelompok OSNA dan kelompok normal, pada kelompok normal antara laki-laki dengan perempuan; serta pada penderita OSNA antara laki-laki dan perempuan dengan menggunakan $t$-test.

Penilaian karakteristik profil jaringan lunak fasial pada penelitian ini ditentukan berdasarkan variabel-variabel berikut.

- Sudut kecembungan fasial jaringan lunak total, yaitu sudut yang dibentuk oleh perpotongan antara garis yang ditarik dari nasion (N') ke pronasion (Pn) dengan garis
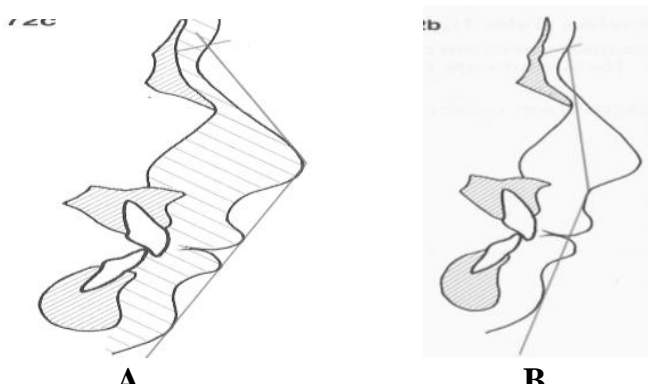

A yang ditarik dari pogonion (Pg') ke pronasion $(\mathrm{Pn})$.

- Sudut kecembungan fasial jaringan lunak, yaitu sudut yang dibentuk oleh perpotongan antara garis yang ditarik dari nasion (N') ke subnasion ( $\mathrm{Sn}$ ) dengan garis yang ditarik dari pogonion (Pg') ke subnasion (Sn).

- Sudut nasolabial, yaitu sudut yang dibentuk oleh perpotongan antara garis yang ditarik dari pinggir bawah hidung ke subnasion (Sn) dan garis dari labialis superior (Ls) ke subnasion (Sn).

- Jarak bibir atas - garis estetik (E-line), yaitu jarak tegak lurus antara bagian teranterior dari bibir atas dengan garis estetik menurut Ricketts (E-line) yaitu garis yang ditarik dari ujung hidung $(\mathrm{Pn})$ ke bagian teranterior dari dagu (Pg').

- Jarak bibir bawah - garis estetik (E-line), yaitu jarak tegak lurus antara bagian teranterior dari bibir bawah dengan garis estetik menurut Ricketts (E-line) yaitu garis yang ditarik dari ujung hidung (Pn) ke bagian teranterior dari dagu (Pg').
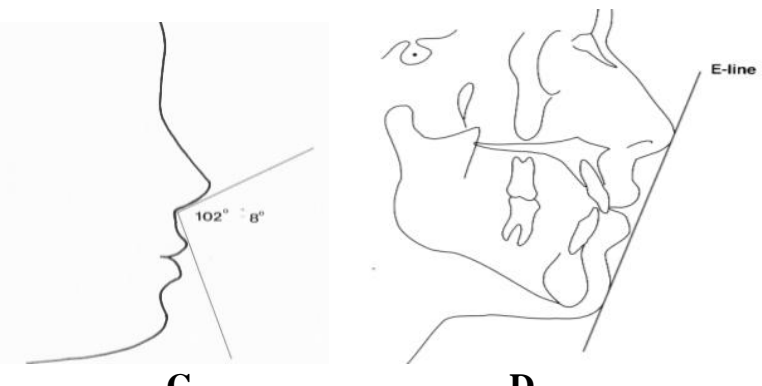

C

Gambar 1. A. Kecembungan fasial jaringan lunak total menurut Subtelny. (Rakosi, 1982) ${ }^{7}$

B. Kecembungan fasial jaringan lunak menurut Subtelny. (Rakosi, 1982)

C. Sudut nasolabial (Jacobson, 1995) ${ }^{8}$

D. E-line menurut Rickett's. (Jacobson, 1995) ${ }^{8}$

\section{Hasil Penelitian}

Jumlah subyek penderita obstruksi saluran napas atas yang diambil sebagai sampel 64 orang, terdiri atas 32 orang laki-laki dan 32 orang perempuan. Jumlah subyek normal 32 orang, terdiri atas 11 orang laki-laki dan 21 orang perempuan. 
Erly Budianto, Miesje K. Purwanegara, Erwin Siregar

Tabel 1. Nilai sebaran dan hasil uji t-test karakteristik profil jaringan lunak fasial antara subyek penderita OSNA dengan nafas mulut dan subyek normal, Jakarta 2003-2005.

\section{Kecembungan fasial total (N'-Pn-Pg')}

Kecembungan fasial

(N'-Sn-Pg')

Sudut nasolabial

Bibir atas terhadap $E$-line

Bibir bawah terhadap $E$-line

\begin{tabular}{ccccc} 
Kriteria & $\begin{array}{c}\text { Jumlah } \\
\text { Subyek }\end{array}$ & Rerata & $\begin{array}{c}\text { Simpangan } \\
\text { Baku }\end{array}$ & P \\
\hline Normal & 32 & $140,91^{0}$ & $5,48^{0}$ & 0,079 \\
OSNA & 64 & $138,98^{0}$ & $4,77^{0}$ & \\
Normal & 32 & $167,34^{0}$ & $5,60^{0}$ & $0,000^{*}$ \\
OSNA & 64 & $161,13^{0}$ & $5,52^{0}$ & \\
Normal & 32 & $94,78^{0}$ & $7,35^{0}$ & 0,053 \\
OSNA & 64 & $91,03^{0}$ & $11,22^{0}$ & \\
Normal & 32 & $-0,45 \mathrm{~mm}$ & $1,53 \mathrm{~mm}$ & $0,000^{*}$ \\
OSNA & 64 & $3,84 \mathrm{~mm}$ & $1,99 \mathrm{~mm}$ & \\
Normal & 32 & $0,86 \mathrm{~mm}$ & $1,86 \mathrm{~mm}$ & $0,000^{*}$ \\
OSNA & 64 & $5,54 \mathrm{~mm}$ & $2,84 \mathrm{~mm}$ &
\end{tabular}

Signifikan pada $\mathbf{p}<0.05 ; *$ Perbedaan bermakna

Hasil uji t-test pada Tabel 1, nilai kecembungan fasial, jarak bibir atas terhadap Eline, dan jarak bibir bawah terhadap E-line pada subyek OSNA berbeda bermakna dengan subyek normal. Nilai $p$ yang diperoleh sebesar $0,000(\mathrm{p}<0,05)$. Hal ini bisa diartikan bahwa subyek penderita OSNA memiliki wajah yang lebih cembung, bibir atas dan bawah yang lebih maju secara bermakna dibandingkan dengan subyek normal.

Tabel 2. Nilai sebaran dan hasil uji $t$-test karakteristik profil jaringan lunak fasial antara subyek normal laki-laki dan perempuan, Jakarta 2003-2005.

\begin{tabular}{lccccc}
\hline & Jenis kelamin & $\begin{array}{c}\text { Jumlah } \\
\text { Subyek }\end{array}$ & Rerata & $\begin{array}{c}\text { Simpangan } \\
\text { Baku }\end{array}$ & P \\
\hline Kecembungan fasial total & laki-laki & 11 & $138,82^{0}$ & $5,85^{0}$ & 0,120 \\
(N'-Pn-Pg') & perempuan & 21 & $142,00^{0}$ & $5,08^{0}$ & \\
Kecembungan fasial & laki-laki & 11 & $164,96^{0}$ & $7,34^{0}$ & 0,080 \\
(N'-Sn-Pg') & perempuan & 21 & $168,60^{0}$ & $4,11^{0}$ & $5,62^{0}$ \\
Sudut nasolabial & laki-laki & 11 & $96,00^{0}$ & 0,506 \\
& perempuan & 21 & $94,14^{0}$ & $8,16^{0}$ & \\
Bibir atas terhadap E-line & laki-laki & 11 & $0,32 \mathrm{~mm}$ & $1,52 \mathrm{~mm}$ & $0,039^{*}$ \\
& perempuan & 21 & $-0,85 \mathrm{~mm}$ & $1,41 \mathrm{~mm}$ & \\
Bibir bawah terhadap E-line & laki-laki & 11 & $1,43 \mathrm{~mm}$ & $1,40 \mathrm{~mm}$ & 0,214 \\
\hline
\end{tabular}

\section{Signifikan pada $\mathbf{p}<0,05 ; \quad *$ Perbedaan bermakna}

Berdasarkan analisis perbedaan menggunakan independent $t$ test tabel 2, pada karaktertristik profil jaringan lunak ditemukan bahwa nilai rata-rata jarak bibir atas terhadap $E$ line mempunyai nilai $\mathrm{p}=0,039(\mathrm{p}<0,05)$. Hal ini menunjukkan bahwa jarak bibir atas terhadap $E$ - line pada subyek normal laki-laki lebih besar secara bermakna dibanding perempuan.

Karakteristik profil jaringan lunak subyek penderita OSNA dengan nafas mulut pada lakilaki dan perempuan. 
Tabel 3. Nilai sebaran dan hasil uji t-test pada subyek penderita OSNA dengan nafas mulut antara laki-laki dan perempuan, Jakarta 2003-2005.

\begin{tabular}{|c|c|c|c|c|c|}
\hline & Jenis kelamin & $\begin{array}{l}\text { Jumlah } \\
\text { Subyek }\end{array}$ & Rerata & $\begin{array}{l}\text { Simpangan } \\
\text { Baku }\end{array}$ & $\mathbf{p}$ \\
\hline \multirow{2}{*}{$\begin{array}{l}\text { Kecembungan fasial total } \\
\text { (N'-Pn-Pg') }\end{array}$} & laki-laki & 32 & $138,4531^{0}$ & $4,67381^{0}$ & \multirow{2}{*}{0,385} \\
\hline & Perempuan & 32 & $139,5000^{0}$ & $4,88909^{0}$ & \\
\hline \multirow{2}{*}{$\begin{array}{l}\text { Kecembungan fasial } \\
\text { (N'-Sn-Pg') }\end{array}$} & laki-laki & 32 & $159,8281^{0}$ & $5,54106^{0}$ & \multirow{2}{*}{0,058} \\
\hline & Perempuan & 32 & $162,4375^{0}$ & $5,25441^{0}$ & \\
\hline \multirow{2}{*}{ Sudut nasolabial } & laki-laki & 32 & $90,9609^{0}$ & $11,07600^{0}$ & \multirow{2}{*}{0,958} \\
\hline & Perempuan & 32 & $91,1094^{0}$ & $11,53238^{0}$ & \\
\hline \multirow{2}{*}{ Bibir atas terhadap E-line } & laki-laki & 32 & $4,4922 \mathrm{~mm}$ & $1,52332 \mathrm{~mm}$ & \multirow{2}{*}{$0,008^{*}$} \\
\hline & perempuan & 32 & $3.1953 \mathrm{~mm}$ & $2.20770 \mathrm{~mm}$ & \\
\hline \multirow{2}{*}{ Bibir bawah terhadap E-line } & laki-laki & 32 & $6.8516 \mathrm{~mm}$ & $2.46987 \mathrm{~mm}$ & \multirow{2}{*}{$0,000 *$} \\
\hline & perempuan & 32 & $4.2344 \mathrm{~mm}$ & $2.59103 \mathrm{~mm}$ & \\
\hline
\end{tabular}

Signifikan pada $\mathbf{p}<0.05$, * Perbedaan bermakna

Berdasarkan analisis perbedaan menggun akan independent $t$ test (Tabel 3), pada karakteristik profil jaringan lunak ditemukan bahwa nilai rata-rata jarak bibir atas terhadap $E$ line dan bibir bawah terhadap E-line mempunyai nilai $\mathrm{p}<0,05$. Hal ini menunjukkan bahwa nilai rata-rata jarak bibir atas terhadap $E$ line dan jarak bibir bawah terhadap E-line pada subyek penderita OSNA laki-laki lebih besar secara bermakna dibanding perempuan.

\section{Pembahasan}

Subyek penderita OSNA terbukti memiliki wajah yang lebih cembung, bibir atas dan bawah yang lebih maju secara bermakna dibandingkan dengan subyek normal. Fenomena ini mungkin disebabkan oleh pengaruh jaringan keras terhadap jaringan lunak di atasnya. Pertumbuhan jaringan lunak dan keras tidak berlangsung sendiri-sendiri, melainkan saling berpengaruh dan saling bergantung. Pertumbuhan otot dipengaruhi oleh pertumbuhan tulang di bawahnya. Soehardono, dalam penelitiannya mengenai profil fasial mengemukakan adanya korelasi positif antara bagian jaringan keras dan bentuk profil muka jaringan lunak. ${ }^{9}$ Menurut Ricketts konfeksitas skeletal dapat dijadikan indikator kontur wajah. ${ }^{4}$
Keadaan skeletal retrognati, adanya rotasi mandibula searah jarum jam, protrusi gigi anterior atas, dan overjet yang besar (gambaran adenoid facies) pada subyek penderita OSNA dengan nafas mulut membuat wajah tampak lebih cembung dibandingkan dengan subyek normal. Selain itu, jarak bibir atas terhadap Eline dan jarak bibir bawah terhadap E-line yang besar pada subyek penderita OSNA kemungkinan disebabkan oleh protrusi gigi anterior atas, nostril yang kecil, dan dagu yang retruded yang sering dijumpai pada penderita OSNA. $^{2}$

Jarak bibir atas dan bawah terhadap E-line dipengaruhi oleh pertumbuhan hidung, posisi bibir, dan pertumbuhan dagu. Pada usia ini, pertumbuhan mandibula pada laki-laki lebih lambat 2 tahun dibandingkan perempuan, sehingga mandibula pada laki-laki nampak lebih retruded dan bibir atas lebih maju dibanding perempuan. Hal ini terlihat baik pada subyek normal maupun subyek penderita OSNA ${ }^{2,10,11}$

\section{Kesimpulan}

Subyek penderita OSNA dengan napas mulut memiliki wajah yang lebih cembung, jarak bibir atas dan jarak bibir bawah terhadap E-line yang lebih besar secara bermakna $(p<0,05)$ dibandingkan dengan subyek normal. 
Hasil penelitian ini menunjukkan subyek normal laki-laki memiliki jarak bibir atas terhadap E-line yang lebih besar secara bermakna dibandingkan perempuan $(\mathrm{p}=0,039)$. Hal serupa juga tampak pada subyek penderita OSNA dengan napas mulut, yaitu penderita OSNA laki-laki memiliki jarak bibir atas danjarak bibir bawah terhadap E-line yang lebih besar dibandingkan penderita OSNA perempuan $(\mathrm{p}<0,05)$.

\section{Daftar Acuan}

1. Bishara SE, Hession TJ, Peterson LC. Longitudinal soft-tissue profile changes: A study of three analyses. Am J Orthod 1985; 88: 20923.

2. Bishara SE. Text Book of Orthodontics. Philadelphia: WB Saunders. 2001: 83.

3. Moyers RE. Handbook of Orthodontics $4^{\text {th }}$ ed. Chicago: Med Pub. 1988: 157,171,200,207-8.

4. Proffit WR. Contemporary Orthodontics. $2^{\text {nd }}$ ed. St.Louis: Mosby. 2000: 75,137-9,207.
5. Purwanegara MK. Karakteristik Maloklusi pada Penderita Pernafasan Mulut di Bagian THT RSUPN Ciptomangunkusumo. Jurnal PDGI ed.khusus 2005: 270-6.

6. Achmad H. Pernafasan mulut pada anak akibat obstruksi saluran nafas atas. Jurnal PDGI ed.khusus 2005: 478-83.

7. Rakosi T. An Atlas and Manual of Cephalometric Radiography. New York: Wolfe. 1982: 80-83.

8. Jacobson A. Radiographic Cephalometry. Chicago: Quintessence. 1995: 114,249

9. Suhardono D. Korelasi Biometrik antar Organ Profil Muka Orang Indonesia (Tesis). Surabaya: Universitas Airlangga. 1983.

10. Van der Linden. Facial Growth and Facial Orthopedics. Chicago: Quintessence. 1987: 1931.

11. Sudarso ISR. Pola kebiasaan dan akibatnya terhadap pertumbuhan dan perkembangan kompleks maksilomandibular fasial pada anak. Jurnal PDGI ed.khusus 2002: 391-400. 